UDC $1 / 14$

Alexander MISHURIN

\title{
SOME REMARKS ON THE FIRST BOOK OF ARISTOTLE’S POLITICS
}

\begin{abstract}
This article is devoted to a sequential analysis of the first book of Aristotle's Politics. It suggests an interpretation of the classical problem of natural hierarchy of men as it described in the first book of the treatise. In this book, Aristotle examines seven commonly held definitions of a slave - four "natural" and three "conventional" ones - and then offers his own eighth definition, placed right in the middle between nature and convention. The article exclusively deals with the first book of Politics and avoids invoking other books of the treatise as well as other works of Aristotle because in classical political philosophy every statement is highly contextualized and could not be simply quoted in order to prove or disprove any point of view without preceding deep examination.
\end{abstract}

Keywords: Aristotle, politics, slavery, mastery, economics.

Aristotle's Politics is a treatise that seems try to show what a state is, what are its parts and then to describe an ideal state - a state which provides happiness for all its citizens as a whole and every citizen individually (1324a 5-8, 2325, 1325a 7-10, 1329a 22-24) ${ }^{1}$. Thus, it seems that the first, introductory, book of Politics is devoted to the origins of social and private life, commonly named by Aristotle as "partnership"

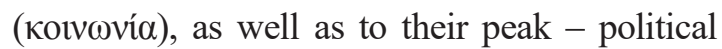
authority.

The first book stands out both against the rest of this work and against other Aristotle's treatises. First of all, touching upon questions which had already been raised before him, Aristotle usually tries to describe or generalize opinions on these matters. Such works as, for example, Physics, Big Ethics, Rhetoric etc. begin in this manner. However, the ideas of other phi-

All references to the Politics are in parentheses. Quotations are from Aristotle, 1959. losophers about both the state and the ideal state are seeming to be discussed in the second book of Politics, not the first one. Secondly, the discussion of family, slavery and economics will no longer be raised after the first book, which is logical, for there is no point in discussing who a slave is if in the ideal state all slaves turn out to be the people who can be granted freedom (1328b 24-29 and 1330a 25-30, 31-33); nor is there any point in discussing the problems of economics or family if in the ideal state only happy people are by default considered citizens, which can be achieved only by excluding from citizens those who are unhappy by definition: children, women, disabled or poor people or manual workers (1328b 5-10, 1328b 33-1329a $2,1335 \mathrm{~b}$ 19-21). In the meantime, weapons are declared to be the guarantee of happiness for the majority of the rest, although the treatise says nothing on how to use them (1297b 1-2, 1328b 7-10, 1329a 16-18). Thus, the first book of Poli- 
tics is separated from the rest of the work both by its subject matter and by its position; hence it is worth taking a closer look at it.

In the introduction Aristotle focuses on three properties of the state as such. The first one is that every state is partnership. The second one is that every state is formed with a view to some "good". Yet in the first book this "good" is not the happiness of all citizens, but only self-sufficiency (Cf., 1252b 27-29, 1252b

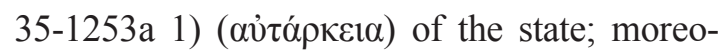
ver, the word "happiness" ( $\varepsilon \delta^{\delta} \delta \alpha \mu$ oví $\alpha$ ) is not used in the first book at all. The third aspect is

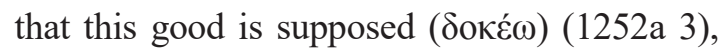
i.e. not true. Indeed, it would be inappropriate to claim the necessity to search and create an ideal state if any state or any regime could reach its goal by default. However, if the state aims for self-sufficiency, then any political system, i.e. any existing regime, will reach it by default. In this sense there is no difference between various types of regimes, for all of them are equally good at reaching this goal. Perhaps, the thing is that the first book deals with the state as such and not with the ideal state, thus it does not impose overestimated standards on it, requiring every state system to be ideal, i.e. providing happiness.

Aristotle continues his research, speaking of the types that embody their imperative position in partnerships. The first two of them are political (governmental): "statesman" and "royal ruler"; the other two are private: "head of an estate" and "master". At the same time, it seems that at least between the two of them (royal ruler and statesman) there is a difference, but, according to Aristotle, it is neither quantitative nor qualitative (1252a 7-16, 1288b 1-2). Since Aristotle next speaks of the two types of partnership that the state derives from (a conjugal partner- ship, or the partnership of equals, and a masterslave partnership, or the partnership of unequals), these four types representing the masterful side of partnership seem to be divided into pairs: royal ruler-master, statesman-head of an estate. Indeed, a royal ruler treats his subjects like a master treats his slaves (1285b 29-33), and a statesman is in the same relationship with citizens as husband is with his wife (1259b 4$10)$. Thus, in order to better understand the concept of state partnership, Aristotle comes to study the two types of private partnerships.

\section{Slavery}

Male-female partnership is necessary and natural and is meant for the sake of reproduction (1252a 26-31). Aristotle says nothing more about the first type of private partnership before proceeding to the second type, the description of a slavery problem. And it really is a problem, for it seems that a master-slave partnership, just like a male-female one, should be natural, dividing the parties to a partnership into two groups: masters and slaves. Yet the very first definition of a slave, given by Aristotle, is problematic. He says that a slave is by nature a ruled human being, the one who does not possess the intellect of his master and thus only capable of employing his body to labor (1252a 31-34). Aristotle then immediately has to declare that woman, who is generally thought to be inferior in intellect to man and predisposed to obedience and physical labor, cannot be a natural slave (1252a $34-1252 \mathrm{~b} 1)$. The teleology principle cannot allow a woman to be predisposed to perform two roles, fulfilling two "natural" purposes at a time. And since it is obvious that women are meant for childbearing, and hence are predisposed to a conjugal partnership rather than that 
of master and slave, Aristotle has to not only decline this definition, but, following the same rule, also completely remove women from any definition of "natural" slavery (Cf. 1260b 1820).

The first definition of a "natural slave" is instantly followed by the second one: a slave is a barbarian (1252b 9. Cf. 1285a 19-22). To support this thesis, Aristotle quotes Euripides and Hesiod $^{2}$. The only thing we know about barbarians from other parts of Politics is the only political characteristic given to them by Aristotle. Its point is that barbarians are people who either have not created the state yet (savages) or who live under monarchy (1285a 16-18, 1285b 23-25, 1295a 11-14, 1327b 23-29). However, this knowledge seems to be enough for Aristotle to contest the second definition of a "natural slave". The philosopher says that the state derives from the family, but several families do not yet constitute the state, and when created, the state inevitably becomes monarchical (1252b 15-27, 1295a 11-14). Aristotle says that "it is owing to this that our cities were at first under royal sway and that foreign races are so still" (1252b 19-20). In other words, if the state is natural, then all peoples go through the following stages: family - several families - kingship (1295a 11-14, 1297b 25-26). And it means, that the Greeks also used to be barbarians $^{3}$. But if a barbarian is a "natural slave", then the Greeks used to be "natural slaves" and then stopped being them, having become "natural masters". Which, of course, would

2 Of the twelve direct quotes, nine are mentioned in the first half of the book, dedicated to the problem of slavery, and only three are mentioned in the second half. Quotes that do not belong to poets are encountered only twice, both times their authors being notable statesmen.

3 Aristotle does not believe in incremental progress, and thus the Greeks can lose the civilization that they created and become barbarians under the king again. mean the impossible: not only did the Greeks manage to disavow their nature, but were also able to acquire a new one.

A couple of strange things arises here. Firstly, speaking of barbarians as "natural slaves", Aristotle points out that they practice the only type of private partnership - a conjugal one. But for some reason he calls it a "partnership of female slave and male slave" (1252b 5-7). How can a notion of a master-slave partnership, which barbarians allegedly do not have by definition, be applied to a conjugal partnership, which, as has already been said, is the partnership of "equals"? Perhaps the matter is that a conjugal partnership is natural and takes place by necessity ( $\dot{\alpha} v \alpha ́ \gamma \kappa \eta)$ (1252a 26), and hence it cannot be part of a master's life, which definitely assumes freedom from any needs or coercion.

Secondly, here Aristotle in his discussion about the state deriving from the family also underlines the unnaturalness, artificialness of civil authorities in particular and civilization as a whole (1275b 32-34) ${ }^{4}$ and then dwells upon the birth of monarchy. According to Aristotle, monarchy is definitely the best form of government (1259b 14-17, 1284a 3-13, 1284b 25$34,1332 \mathrm{~b} 16-23)$ also because it is the only natural form of government (1285b 29-35) $)^{5}$. And, importantly, kingly rule does not derive from a master-slave partnership (See, for example (1279a 17-21) (which would be impossible in

4 It actually does not prevent the artificial civilization from deriving from natural barbarity. Thus, artificial trade, for example, directly derives from natural barter exchange. (See 1257a 1-6, 30-31).

5 This argument is supported by the fact that monarchy is the only regime without two poles: its lower pole is a life-time strategy, which is not monarchy at all (See 1285a 3-10, 1287a 3-8). It is also supported by the fact that tyranny - as opposed to monarchy - can arise from other political regimes, and is most similar to democracy in terms of its origin and its modes of action (See 1284a 33-36, 1285a 29-33, 1286b 16-17, 1292a 15-20, 1310b 2-4). 
case of "barbarians"), but directly from a conjugal partnership: "for every household is under the royal rule of its eldest member" (1252b 2022, 1255b 18-19, 1259a 39-1259b 1, 10-11).

But we have to get back to the slavery problem. Having contested the first two "natural" definitions, Aristotle introduces a third one. What if a "natural slave" is not human at all, but a beast in a human disguise? This definition is discussed in the fragment dedicated to two types of persons capable of living outside of state partnership: "inferior man” ( $\varphi \alpha \tilde{\lambda} \lambda \circ \varsigma$ öv $\theta \rho \omega \pi \circ \varsigma)$ and

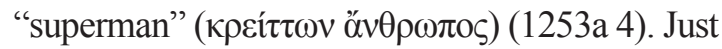
like conjugal partnership, political partnership is natural, i.e. "necessary", that is why those who do not belong to it are either bad people or supermen who have dedicated their lives not to politics, but to a superior, contemplative activity, for only such activity can lead to happiness (1324a 23-25, 1325b 16-21, 1328b 33-1329a 2, 1334a 20-23). In this sense, a person who has voluntarily refused to enter into conjugal partnership can be considered a superman, whereas the one who is not able to enter into such a partnership, is considered inferior. At the end of this argument Aristotle comes to speaking not about "inferior man" or "superman", but about a

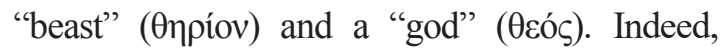
people who live outside of political partnership (savages) do exist, but does it mean that they, like "talking livestock", are "natural slaves"? To contest this argument, Aristotle also accepts a different point of view saying that all animals, both wild and domestic, exist only to serve men (1254b 10) $)^{6}$. Thus, if anyone were a "beast" in a human disguise, they would actually have to be "natural slaves", i.e. would be bound to serve men. However, according to Aristotle, there are

6 Cf. with a less radical version of the same statement (1256b 15-22). two features that distinguish human beings from animals: speech and the ability to perceive moral values, such as justice and injustice, good and evil (1253a 14-18). Let us forget for a moment that there are no humans without speech (the exceptions only confirm the rule here, since a slave who cannot understand his master is as useful as an animal) (1259b 25-28). Let us also forget that all types of political and private part-

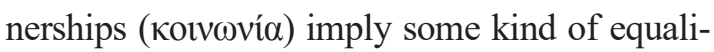
ty, i.e. relationships between human beings. Even after getting rid of these arguments we will have to agree with Aristotle on the fact that state ("political partnership") and law, an integral part of state (1253a 37-38), both rest on the notion of justice (which is also vital for other types of partnership) and that, consequently, a creature which has no idea about justice and which does not possess it, cannot enter into the partnership (1253a 35-38, 1260a 20-1260b 5). That is why political partnership (and all other types of partnership) includes only people and does not include inanimate objects and other creatures.

Having contested the first three definitions of a slave ("natural slave"), for the first time Aristotle mentions that not all people agree with the existence of natural slavery, and that some people think that for one man to be another man's master is contrary to nature (1253b 21-22) ${ }^{7}$. But instead of speaking about conventional theories of slavery, Aristotle seems to give the first generalized definition of a slave as a man belonging to another man by his nature (1254a 14-15) ${ }^{8}$. The philosopher describes several examples of natural hierarchy: body-soul (1254b 4-5), male-

7 The slavery's unnaturalness is supported by the fact that there is a possibility to completely get rid of it (See 1253b 37-1254a 1).

8 Earlier he gives the same but slightly paraphrased definition of a slave as a "tool" (1254a 5-8). 
female (1254b 13-14), man-beast (1254b 10-13). These examples state the supremacy of the reasonable nature. He whose body is more developed, i.e. more suitable for dull physical labor, will be the "natural slave" (1254b 16-19). Coming to this conclusion, Aristotle once again gives a generalized definition of a slave, underlining the relevance of the slave's status regardless of its implementation (Cf. 1254a 14-15 with $1254 \mathrm{~b}$ 20-21). Truly, the body can dominate the soul, the woman can dominate the man, the beast can compel the man (to flee, for example), but it will not anyhow change their natural status. A slave is always a slave, regardless of his legal status: either he is free, or a master, or a citizen, or a metic etc. Now, there are several problems with the definition of "natural slave" as a physically strong person. Firstly, a physically strong person can also turn out to be mentally strong, i.e. physical strength itself says nothing about natural predisposition to slavery. "Natural masters" can have both weak and strong bodies (1254b 3234). Secondly, physical strength is part of bodily perfection, and this is the way people picture gods $^{9}$. And physically perfect people are as superior to regular people, as the gods superior to themselves (1254b 34-36). But then we would have to state the impossible - that the gods are superslaves. Thirdly, nothing would stop physically strong people from making physically weak people their slaves (1255a 9-11). On the contrary, this state of affairs would quite correspond with the natural hierarchy of bodies. Next, says Aristotle, besides the hierarchy of bodies, there is the hierarchy of souls, which would be much more appropriate to use to define the "natural status" of masters and slaves (1254b 37-39). For

Aristotle says nothing about moral supremacy of pictured gods over people, only about their physical supremacy. the soul, as has already been said, is superior to the body in the natural hierarchy. However, the implementation of this approach to classify people would require the existence of a completed science of the soul ${ }^{10}$, as well as a developed institution of its application. In other words, this approach would assume that the first step to establish an ideal state would require its existence. Therefore, in spite of the abovementioned conclusion, Aristotle does not cease to delve into the problem of slavery.

The contestation of four concepts of natural slavery is followed by the contestation of three concepts of conventional slavery ${ }^{11}$, to which Aristotle pays much less attention. This is partly connected with the fact that all conventional concepts of slavery are relativistic. The problem with relativistic concepts is that, although they are perfect for describing or even explaining of what happens in partnership, they nevertheless do not establish anything: it is impossible to base a reliable order on their ground. Thus, "legal slavery", usually the result of military conquest, is unacceptable, because in this case anyone, as a result of any chance, can become a slave (1255a 21-28). A yesterday's winner can become a today's loser; a yesterday's slave, as a result of a successful revolt, can become a today's master. Therefore, the same person can "legally", i.e. in a just manner, change his position from master to slave and vice versa. Not to mention the fact that with such kind of concept of justice any successful revolt is considered just and "legal" (likewise, any unsuccessful revolt is considered unjust and "illegal"). But Aristotle even doubts if all the

10 Which Aristotle tries to develop in the corresponding treatise.

11 The mere existence of which questions the initial statement about the naturalness of master-slave partnership. 
wars can be just (1255a 24-26, 1256b 23-26) ${ }^{12}$.

The same happens when nobility is considered as a reason for being a master. Either nobility is universal (then we should have universal theology and accept the existence of "ever-free" noble barbarians), or there are two types of nobility: true (Greek) and false (barbaric). But in this case it is not about inheritance of blood, but the inevitability of inheriting virtues, which is, of course, far from the truth (1255b 1-4).

Finally, Aristotle speaks about the existence (or the probability of the existence) of "slave's science". Slave's science is the knowledge of how to carry out slave's duties, and anyone can learn it. Hence it says nothing of who a slave is (1255b 22-30). Similarly, states Aristotle in contradiction to Socrates, knowledge does not constitute virtue and therefore says nothing of a master and a free man. At this point Aristotle declares the ending of the discussion on the slavery problem (1255b 39-40), confusing the reader. He will come back to it at the end of the first book, offering his own - and the last - way to resolve it (1259a 37-1260b 7). Thus we may assume that all this time Aristotle has been discussing common and popular philosophical ideas of slavery $^{13}$, thus preparing necessary grounds to introduce his own decision.

In order to give his own definition of slavery, Aristotle, at the end of the first book, goes back to the beginning - to family (1259a 37-39). Here he openly says that both imperative positions in political partnership - a royal ruler and a statesman - derive from the family, whereby kingly rule derives from the authority of father

12 Although certainly there can be just, i.e. legal, grounds for revolts (See 1302a 22-29).

13 All concepts of "natural" slavery can be regarded as popular, because, when discussing them, Aristotle quotes poets, whereas when discussing conventional concepts, he repeatedly mentions some "other" or nameless "wise men". over children, and statesman's authority derives from the authority of husband over wife. However, this argument seems rather strange. The authority of a statesman is characterized as the authority over equals, like a "temporary", changeable authority (1259a 40-1259b 1), while kingly rule is the authority over unequals $(1259 \mathrm{~b}$ $1,10-13)$. But how can the authority of husband over wife be like statesman's authority, if, as Aristotle has already explained, men and women are not equal (1254b 13-14)? Besides, it is obvious that a woman will never be able to replace her husband in his authority; it is children who are really likely to "replace" their father, by becoming fathers themselves and thus gaining an equal legal status. Anyway, master-slave partnership does not give rise to any type of political partnership, and in this sense there is actually no difference between a statesman, a royal ruler and a head of an estate, as in any case the father of the family has both roles. But how then can a slave become part of state partnership or in that case any other partnership? ${ }^{14}$ Aristotle gives a rather surprising answer to this question. A slave, being human (1259b 27-28), in the same way as any other human being, should possess virtue, which will enable him to enter into the partnership (including political partnership) and be a member of political community. In other words, Aristotle says that a slave is a virtuous human being (1259b 39-1260a 1). He must possess virtue, otherwise he is not only useless, but even harmful in any partnership (1260a 1-2). But what kind of virtue is this? Any partnership (especially a political one) requires only one virtue from its members - justice (1253a 34-38, 1259b 391260a 1, 1283a 37-41). I.e., a slave is a just

14 We should not forget that Aristotle also names a conjugal partnership as a "slaves" partnership. 
$\operatorname{man}^{15}$. But as it has already been said that all types of partnerships require justice from their members (and nothing more), anyone who enters into any of these types of partnership becomes a slave. At this point public legal hierarchy loses its sense. A legally free lawful master, a metic, a woman, a child etc. all become the same slaves as an actual legal slave. In the same sense we should understand Aristotle's words about different levels of the same virtue. Justice as lawobedience, as a relation to the law really gives different legal statuses to different categories of people (1260a 12-13). Thus, in a civilized society, a citizen (father and master) can take part in lawmaking. His male children can eventually acquire full civil rights, i.e. the rights to participate in lawmaking. His wife, although being a citizen, will never receive such a right, but is still bound to obey laws; slaves, not being citizens at all, are still bound to obey laws.

This definition of slavery is right in the middle between "natural slavery" and conventional slavery, as pursuit of justice or the virtue of justice, requiring to obey laws (written and unwritten), is natural, but the laws themselves (written and unwritten) are the result of convention. Now it is clear why Aristotle says that in the ideal state all (legal) slaves can be freed. It also explains the incompleteness and insufficiency of politics compared to a natural purpose of man. In this sense, politics cannot be the activity of genuinely free people - true masters. Moreover, slavery thus understood relieves us from the necessity to have a perfect science

15 Aristotle credits a legal slave (after his master) with two virtues - moderation and justice (1259b 391260a 2). But answering the question whether there are people inferior to slaves (less virtuous), Aristotle says that, although such people do exist (craftsmen), of the two virtues even they only lack one moderation. (They are "intemperate" and intemperance $(\dot{\alpha} \kappa \circ \lambda \alpha \sigma i \alpha)$ is the opposite of moderation

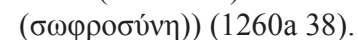

about the soul, as well as the institution of its application in order to understand who is a slave and who is not. It is enough to see who obeys the law and who does not. Or, more precisely, to see who is just and who is not. That is because, as it seems now, only among unjust people and people who refused to enter into specified types of partnerships should we find those who are genuinely free - the true masters.

\section{Mastery}

After we have learned the definition of a true slave, it seems inevitable that we should also find the entity of a true master. We are aware that a true master does not participate in any of the three types of partnership and does not possess a virtue of justice (as lawobedience). This is a definition of a "superman", already mentioned by Aristotle, who is able to live "outside of society". Indeed, Aristotle states that a "superman" or a "god" is the one who can live outside of the three types of partnership without obeying laws (that is, not to possess slave's virtue). Such person is "by nature citiless and also a lover of war", he lives by war (1253a 6, 31-33, 1255b 37-39). But how exactly does this person live? It is obvious that he is not deprived of interaction with other people, he is neither an outcast nor an ascetic, who is forced to survive rather than live, for otherwise how could he be happy? Freedom from the necessity to take part in the three types of partnership does not relieve him from the need for nutrition, shelter, sleep etc., i.e. things that a single person is not able to provide himself with, especially if he also claims to have leisure, an integral element of happiness (1338a 1-4).

In order to puzzle it out, Aristotle begins to study all types of life styles and activities 
available for a man. There are two ways of making a living: exchange and production. Initially Aristotle divides production into three categories: cattle breeding, hunt (which, according to Aristotle, also includes manhunt) and agriculture (1256a 30-35), hunt having a crucial - middle - position between the two poles $^{16}$. It is followed by a detailed list of activities where the pride of place goes to robbery (manhunt) (1256b 1-2). In this sense Aristotle declares "slave hunt" not only acceptable, but even just (1256b 23-26). It seems that the philosopher contradicts himself, saying that a master can show justice by hunting a slave. But in the new context all three notions (slave, master, justice) are no longer bound by a legal status. In other words, a true master can "hunt" true slaves, who can be, for example, full citizens rather than legal slaves. Moreover, since the definition of a true slave is closely connected with the definition of justice as lawfulness, true justice turns out to be its direct opposite (1328b 33-1329a2, 1284a 10-14). Hence, true justice contradicts any public order, and thus any regime, for every state gives rise to and maintains order (this may be another reason why the first book does not divide different regimes). Even tyranny, declaring the tyrant's word as law, in this sense also gives rise to and maintains order, like any other regime (Xenophon, 1997, I, 2, 41-46).

Later Aristotle repeats his list, this time speaking about the ways of earning money, which are three: agriculture, exchange and agriculture joined with exchange; the philosopher reminds us that the best of them is in the middle (1258b 27-28). To prove it, Aristotle suggests comparing them by four criteria: value of luck,

16 The middle position has a great role in Aristotle philosophy (See, for example 1342b 14-15). chance of injuring the body, intensity of physical labor and necessity in virtue. Since of the three types of earning money two of them deal with agriculture, they have the highest value of luck, highest chance of injuring the body, highest intensity of physical labor and lowest necessity in virtue. That is why they are inferior to exchange. However, Aristotle also names several types of exchange: trade, usury and selling own physical labor (1258b 20-25); usury (previously called unjust) being in the center. In order to understand which of them is the best, we should once again apply the proposed method of classification (1258b 35-39). It turns out that of the three types of exchange "the most unworthy" one is selling own physical labor, as it is most connected with body injury. This type of exchange is also "the most servile", as it requires the use of physical force. It also is the "most ignoble", since it does not imply any virtue, for any animal is capable of serving with its body, but it is obvious that animals do not have virtues. Now "the most scientific" of them is usury, since chance, compared to trade or selling own physical labor, plays the least important role in it. Of the four criteria only one is positive, and the other three are negative. But these three negative criteria can easily be turned "upside down" to make them positive, thus finding out which type of exchange (and earning money) is the best. It is obvious that "the most worthy" and "the master's" type of exchange is usury, since it is the least to use body and put it at risk. But what about virtue? It is clear that trade is far more connected with justice as lawfulness rather than usury, at least because the latter is often outlawed. But justice as lawfulness and true justice, as has already been said, not only differ, but are directly the opposite. That is why usury, unjust and "hated", is 
"the noblest" and thus the most suitable type of earning money for a true master (1258b 2-3).

Let us assume that a superman living in the society will inevitably be a criminal. But how is it possible to distinguish an ordinary criminal from a superman? And is it possible at all? To answer this question, it is the only time in the first book that Aristotle uses the method of historical example. He comes up with two stories about the same economic crime - securing a monopoly. This unique binary example instantly draws the reader's attention, literally demanding comparison. Thus, it seems that there is no point in telling two stories on the same topic in a book where no other topic can boast of a historical example. The first story tells about Thales of Miletus, a philosopher who proved his wisdom ( $\left.\sigma \circ \varphi^{\prime} \alpha\right)$ by his actions. It is worth noting that for a few lines dedicated to this story, the word "wisdom", which is not seen anywhere else in the first book, is expressly used twice, as well as the word "philosophy" is $(1259 \mathrm{a} 8,10,16,19)$. Thales, taking advantage of his scientific knowledge to forecast a large crop of olives, hired all the olive-presses at a low rent in his hometown and Chios, thus securing a monopoly and eventually raising oil production prices (1259a 9-19). The other story tells about a nameless Sicilian who borrowed money to buy up all the iron from the iron foundries of Syracuse, and when the dealers came, he started to sell it as a monopolist with a slightly raised price (1259a 23-31). However, when tyrant Dionysius learned about his monopoly, he banished him from the town, although allowing him to keep the earned money. Speaking of this man, Aristotle never mentions his wisdom nor does he say the word "philosophy". So what is the difference between Thales, a "wise philosopher", and an unwise nameless
Sicilian? Firstly, Thales predicted the demand, whereas the Sicilian knew about it. In other words, Thales was the only one to know about the abundance of olives, and in the second story everyone knew about the arrival of the dealers. Secondly, Thales hired olive-presses on his "small sum of money", but he demanded the price "on what terms he liked" (1259 11-16). The Sicilian used borrowed money to buy iron, but he made a very small markup (1259a 2328). Thirdly, Thales was not punished for his crime (or, more precisely, Aristotle does not say anything about what happened to Thales after his affair), while the Sicilian was caught and punished by authorities (and Aristotle does not conceal that fact). To sum up, Thales managed to "prove his wisdom" not by securing the monopoly (anyone can do it), but by, first of all, maximizing the profit compared to investments, and secondly, by avoiding punishment and escaping liability for a committed crime. This seems to be the way that Aristotle proposes to distinguish a true master from an ordinary criminal. Having committed a crime - but guided by pursuit of true justice - a superman reveals his nature by the scope of the crime (the amount of profit) and by subsequently escaping liability ${ }^{17}$. The second aspect makes the superman's activity nearly invisible, inexistent or existent out of public sight, but it still remains antisocial, i.e. keeps being a truly just activity of a truly free master.

Together with the understanding of what true slaves and masters are, comes not only the comprehension of further content of the treatise, motivated by the creation of a society where a superman could live, prosper and be happy, but also the realization of the problem of politics as

17 True virtue allows committing any crime (Plato, 1937, 331c). 
such, which is that the ideal form of state monarchy ruled by a superman - and the best form of state for a superman to fulfill his superhuman potential do not match. That is because in ideal monarchy a superman would be the one to rule (1332b 16-23), i.e. he would have to partake in political partnership ${ }^{18}$ and to obey laws (1295a 7-17), thus denying his self and turning from a true master into a true slave ${ }^{19}$.

Wealth

Aristotle does not specify any motives and, accordingly, types of crimes for a true master other than economic. It seems clear that a superman would not commit crimes in the heat of passion or motivated by the lust for power. $\mathrm{He}$ is interested in being in the society for as long as it is capable of ensuring his prosperous and well-off being or making his life full of leisure, which is an integral element of happiness. But why is happiness directly connected with leisure or consumption, and not with labor or work? An answer to this question, according to Aristotle, roots in nature itself. If nature created everything for the man's good, it is obvious that a superman, as the top of human hierarchy, should not be in need of labor at all, should not create anything: everything should be given to him for free, it should literally "grow on trees"

18 Aristotle leaves aside the question about what kind of life deserves favor, political or non-political, considering it completely resolved (See 1324a 1322).

19 It can also be mentioned that, on the part of a superman, the problem of politics becomes even more complex, since his natural asociality volens nolens makes him an enemy of any public order, makes him hostile to any political regime. The closer a superman reaches his ideal, the more destructive his activity will be for the society he lives in. In particular, this is the reason why one of the most significant features of the best regime, according to Aristotle, is its stability (See 1319b 33-1320a 4). (1258a 23-24, 34-38). Only then will he be able to live the best life, suitable for his nature (1256b 6-7). But it does not necessarily mean that a superman does not need artificially created (or cultivated) objects. And if he does, then he needs labor, too (1253b 33-1254a 1). To solve this problem, Aristotle divides all human activity into action $(\pi \rho \tilde{\alpha} \xi 1 \varsigma)$ and production

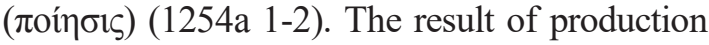
is creation of objects; action assumes the use of objects. If nature created everything for the man's good, it is obvious that the man should be able to use all the goods that the nature provides him with, i.e. his life should only involve action (1254a 7). But the difficulty is that although nature created everything for the sake of man, it is clearly not enough for a prosperous and leisured life. Production must overcome this natural drawback. Thus, in pursuit of a "good" life, a man enters into a "bad" life: starts production, creates or cultivates some objects and exchanges them for other objects that he needs more (1257a 25-30). However, life full of creation and exchange of goods is far from its natural ideal. Here production comes to the aid for the second time: a simple (natural) barter transforms into a complex (artificial) barter - money exchange (1257a 30-31). And since money is the universal equivalent and object at the same time, then, although earning money is production, spending money (to get any other objects) is action. Therefore, having money means possessing all objects which are necessary for life, and hence, having money is the guarantee of being able to live actively in conformity with nature and, as a result, the guarantee of a good life. But since money is an unalienable attribute of society - a civilized society, to be precise, and its role is the more significant, the more developed, or civilized, the society is, then action, 
in conformity with nature, becomes truly possible only in the most developed (i.e. productive) society. Moreover, this society should be as stable as humanly possible (1320a 4), strictly because money, being a universal equivalent not by nature, but by convention, loses its significance with every social shock ${ }^{20}$ (change of political regime, war etc.) (1257b 10-14) Thus, only wealth can allow a person to live a good life (full of activities). Besides, this life will reflect natural hierarchy, as it will be founded on "bad" life (associated with production). This explains strong interest of a superman in onetime maximum enrichment with minimum investments, which is possible only by economic crime or usury as the best and the "noblest" method of automatic production of money out of money.

However, with the introduction of a universal equivalent, a new problem arises: the art of money making becomes the art of arts. As a result, this art, and not the goal of active life, starts to subdue human existence. Aristotle describes this problem as follows. Any art has limited resources to achieve its goal, which is not at all limited (1256b 34-37, 1257b 23-24). This is connected with the abstractness of the goal and the corporeality of resources (1257b 25-30): a cook does not need one hundred pots to cook, a surgeon does not need one hundred scalpels to operate, a father does not need one hundred beds to put his child to sleep etc. Furthermore, a man who would continuously collect the same object would very likely be declared mad. The feature of the art of money making is that its resources are unlimited, because they are abstract. Thus, a man who infinitely gets money is not only con-

20 This is another argument against the only natural regime - kingship - in favor of artificial, "civilized", regimes. sidered not mad, but instead, is commonly recognized as successful (for abstract money can always turn into objects) (1258a 1-2). Moreover, if money allows to live an active life that a man must aim for, it turns out that not only slaves, craftsmen and traders are involved in production, but also those who, at a first glance, are involved in action. Thus, people involved in the medical or pedagogic art or even the art of war are in fact involved in the art of money making (1258a 1014). But money making is production, and since accumulating money is not limited by anything, involvement in it dedicates the whole life of a person to production rather than action. Pointing out this problem, Aristotle, however, does not propose a solution. The reason of this inaction is as follows. It is clear that only a god can totally avoid production. Even a superman in his best manifest has to deal with it at least once; all other people will form a hierarchy, the foundation of which consists of those who are mostly involved in production, i.e. the worst men - craftsmen ${ }^{21}$. But the art of money making turns everyone into craftsmen. The hierarchy collapses: only the top and the foundation remain. It seems that even in this aspect a gap between a superman and other men will inevitably emerge. But Aristotle does not mind it at all. For it is this state of affairs that gives the superman a chance to live actively through one-time maximum profitable unlawful enrichment.

Speaking of the first book of Politics now, we must admit that it plays a far more significant role than a simple introduction dedicated to the origins of politics. Explaining these origins, the first book sets a framework and a goal for the whole treatise; it poses and describes one of the aspects of the problem of politics; it answers

21 Cf. with a common definition of a slave as a "tool of action" (1254a 8). 
the question about whom this ideal state is searched for. And it does so with a shocking honesty and logic, thus creating an impression that it should not explain what we will see in other books of Politics, but on the contrary, the content of the whole treatise in fact serves as a lengthy explanation to its introduction.

\section{REFERENCES}

Aristotle (1959). Politics. (H. Rackham, Trans.).
Plato (1937). Republic. Books I-V. (P. Shorey, Trans.). Cambridge: Harvard University Press.

Xenophon (1997). Memorabilia. In Memorabilia, Oeconomicus, Symposium, Apology (E. C. Marchant., Trans.), pp. 3-380. Cambridge: Harvard University Press.

Cambridge: Harvard University Press. 